\title{
The Role of International and Regional Quality Assurance Bodies
}

\author{
Evelyn Chiyevo Garwe, Lovemore Gwati \\ Zimbabwe Council for Higher Education, Harare, Zimbabwe
}

Email address:

garweec@gmail.com (E. C. Garwe)

\section{To cite this article:}

Evelyn Chiyevo Garwe, Lovemore Gwati. The Role of International and Regional Quality Assurance Bodies. Higher Education Research. Vol. 3, No. 1, 2018, pp. 15-22. doi: 10.11648/j.her.20180301.14

Received: December 29, 2017; Accepted: January 31, 2018; Published: March 19, 2018

\begin{abstract}
This paper gives an overview of the existing models and examples of regional and international higher education quality assurance arrangements. In the case of regional quality assurance arrangements, whilst acknowledging that these exist in all continents, the authors deliberately and specifically provide examples on developments in Africa. Although no particular model is proposed, the authors recommend that, by adopting good practices from the different models, it is possible to foster greater international cooperation as a way of responding to the regulatory demands of globalisation.
\end{abstract}

Keywords: Quality Assurance, Higher Education, Partnerships

\section{Introduction}

Current developments in higher education have prompted countries to establish national higher education quality assurance bodies to regulate and promote quality. These developments include massification, privatisation, marketisation, diversification, institutional restructuring, emerging modes of delivery, accountability demands, globalisation, corruption, fraud and dubious quality assurance practises $[1,2]$. The current trend follows renewed impetus to reaffirm higher education as a catalyst of socio-economic development [3-6] The role of higher education institutions (HEIs) is to produce graduates who can operate efficiently and effectively in a globalised economy. The rapid increase in the number of national and transnational higher education providers raises questions of quality [7]. Several governments worldwide have acknowledged the efficacy of quality assurance (QA) in regulating and enhancing the quality of higher education [8]. Accordingly, several countries have established national higher education quality assurance agencies [9-12]. However, the globalisation of higher education makes it difficult for national QA agencies to monitor and regulate quality in international higher education [13-15]. Such a development has called for a rethink of innovative ways to strengthen quality assurance systems and make them better prepared to cope with challenges regarding quality of higher education [16].

The situation calls for more collaboration and cooperation among nations and quality assurance systems. Although the objectives of national QA agencies are largely similar, there is diversity in the way they operate within the different national contexts regarding funding, capacity and level of commitment [17]. Regional and international bodies, networks and associations have been established for purposes of creating synergies through sharing good practices, information and experiences. Regional and international quality assurance bodies thus complement the work of national QA agencies in protecting learners from poor quality providers thus maintaining the integrity of higher education. These networks enable systematic benchmarking of QA bodies against internationally acclaimed good practices and also serve as mechanisms to assure quality of QA bodies.

Table 1 shows statistics of some Regional and International QA Agencies and Networks. The authors sought to unravel the various forms or models that these regional and international bodies are taking. In addition they intended to analyse the extent to which the different models were achieving the intended objectives of strengthening QA systems in higher education and complementing national QA systems. 
Table 1. Examples of International and Regional QA Agencies and Networks.

\begin{tabular}{|c|c|c|c|c|c|}
\hline & Africa & Arab States & Asia-Pacific & Europe & Global \\
\hline No of QA Agencies & 21 & 14 & 31 & 40 & \\
\hline $\begin{array}{l}\text { No of Countries in } \\
\text { Region }\end{array}$ & 54 & 22 & 53 & 47 & 196 \\
\hline $\begin{array}{l}\text { Name of Regional } \\
\text { Body/Network and } \\
\text { year of } \\
\text { establishment }\end{array}$ & $\begin{array}{l}\text { African Quality Assurance } \\
\text { Network (AfriQAN) } 2009\end{array}$ & $\begin{array}{l}\text { Arab Network for } \\
\text { QA in Higher } \\
\text { Education } \\
\text { (ANQAHE) } 2007\end{array}$ & $\begin{array}{l}\text { Asia-Pacific } \\
\text { Quality } \\
\text { Network } \\
\text { (APQN) } 2002\end{array}$ & $\begin{array}{l}\text { European Association } \\
\text { for Quality Assurance } \\
\text { in Higher Education } \\
\text { (ENQA) } 2000\end{array}$ & $\begin{array}{l}\text { International Network } \\
\text { for Quality Assurance in } \\
\text { Higher Education } \\
\text { (INQAAHE) } 1991\end{array}$ \\
\hline Year Established & 2009 & 2007 & 2002 & 2000 & 1991 \\
\hline $\begin{array}{l}\text { Sub-Regional } \\
\text { Networks }\end{array}$ & $\begin{array}{l}\text { 1. African and Malagasy Council } \\
\text { for Higher Education (CAMES); } \\
\text { 2. Inter-University Council for } \\
\text { East Africa (IUCEA; and } \\
\text { 3. Southern Africa Quality } \\
\text { Assurance Network (SAQAN) }\end{array}$ & $\begin{array}{l}\text { Mediterranean } \\
\text { Recognition } \\
\text { Information Centres } \\
\text { (MERIC) }\end{array}$ & & $\begin{array}{l}\text { Central and Eastern } \\
\text { European Network for } \\
\text { Quality Assurance } \\
\text { Agencies in Higher } \\
\text { Education (CEENQA) }\end{array}$ & \\
\hline
\end{tabular}

Source: [18].

\section{Methodology}

The authors reviewed the existing models of regional and international QA bodies in existence to establish their modus operandi. The exercise also permitted the authors to establish how the existence of regional and international quality assurance bodies is contributing to quality enhancement in higher education with the aim of recommending a suitable model. The methodology used to carry out the study was premised on extensive desk research which involved documentary review of publications and other relevant information available on the internet as well as various websites. On one of the models of regional quality assurance bodies one of the authors was attached to IUCEA for a month during which time he carried out interviews with key members of the regional QA body.

\section{Findings}

During the extensive desk research which involved documentary review of publications and other relevant information available on the internet as well as various websites the authors identified four distinct models of international and regional QA bodies. These models and the examples thereof are explained below:

\subsection{Models of Regional and International Quality Assurance Bodies}

The first model is premised on promoting networking, cooperation and exchange among national QA bodies in an attempt to converge the systems through international benchmarking of standards and procedures as well as continuously transforming the current QA frameworks to cater for emerging developments [19]. Examples of regional and international bodies operating using this model are the African Quality Assurance Network (AfriQAN) and the International Network of Quality Assurance Agencies in Higher Education (INQAAHE).

The second model involves fully-fledged collaboration, for example joint quality assurance strategies as well as mutual recognition of credits and qualifications among QA bodies at a regional or international level [20]. Examples of regional and international bodies operating using this model are the Inter University Council for East Africa (IUCEA) and the Conseil Africain et Malgache pour l'Enseignement Supérieur (CAMES) meaning the African and Malagasy Council for Higher Education.

The third model involves a conceptual framework of the meta-accreditation of quality assurance systems and bodies culminating in international recognition of the QA. An example is the proposed Continental Quality Assurance and Accreditation Agency for Africa.

The fourth model focuses on quality assurance arrangements on the international level and is totally different from the first three. Its primary focus is strengthening the national quality assurance bodies. An example is that of the European Consortium of Innovative Universities (ECIU), a network of that developed its own external quality assessment process to accredit selected Master's Degree programmes.

\subsection{Model 1: Networking, Cooperation and Exchange}

This is the predominant model of sub-regional, regional and international cooperation. The model respects the sovereignty of national QA agencies in safeguarding the national interests and protecting diversity in QA [21]. National QA agencies are strengthened by strong cooperation, collaboration and sharing information and best practices among QA agencies in the region or internationally. The cooperation among QA agencies fosters trust beyond borders in QA in higher Education. Agencies also share and assist each other in capacity building and resource mobilisation. The examples of regional (AfriQAN) and international (INQAAHE) QA networks will be explored further.

\subsubsection{The African Quality Assurance Network (AfriQAN)}

AfriQAN was established under the auspices of the Association of African Universities (AAU) in 2009 as a network of agencies in charge of QA issues relating to higher education in Africa [22]. AfriQAN advances African 
collaboration and co-operation in QA and provides support to its members and stakeholders in order to enhance the quality of higher education in Africa [11]. AfriQAN collaborates with similar organizations from other continents particularly in Europe and America. The Network gets financial support from the Association of African Universities (AAU), the European Union, the Global Initiative for Quality Assurance Capacity (GIQAC), membership subscriptions as well as other well-wishers.

The objectives of AfriQAN are to:

(i) Promote harmonised QA standards in African countries thereby creating a competitive African higher education space;

(ii) Encourage cooperation and association among African QA bodies within Africa;

(iii) Inculcate a QA culture in African higher education institutions;

(iv) Advance research on issues of QA in higher education;

(v) Promote and build capacity in QA;

(vi) Advance and communicate good practices in QA;

(vii) Encourage and assist in the establishment of national and sub-regional QA bodies in the African countries and sub-regions that have not yet established them;

(viii)Create a database of experts, peer reviewers and consultants in QA

(ix) Support members in matters related to QA;

(x) Promote mobility of students, staff and researchers in Africa; and

(xi) Represent the interests of Africa in global QA associations and fora.

The structure of AfriQAN is made up of three levels as follows:

a) The General Assembly which consists of all members in good standing. The General Assembly is the supreme decision-making body of AfriQAN;

b) The Executive Board comprises of a President, VicePresident, Treasurer, representatives of the five African sub-regions and four observers. The Board is elected once every two years. The current Board (2015-2017) has the following members:

(i) President from the National Universities Commission (NUC) of Nigeria, (represented by Professor Chiedu Mafiana);

(ii) Vice-President from CAMES in Burkina Faso (represented by Professor Bertrand Mbatchi);

(iii) Treasurer from the Council on Higher Education (CHE) in Lesotho (represented by Professor Victor Polaki);

(iv) Representative of West Africa from Autorité Nationale d'Assurance Qualité de l'enseignement Supérieur (ANAQ-Sup) in Senegal (represented by Professor Papa Gueye);

(v) Representative of East Africa from Tanzania for Commission for Universities, (TCU) in Tanzania (represented by Professor Eleuther Mwageni);

(vi) Representative of Southern Africa from the
Zimbabwe Council for Higher Education (ZIMCHE) in Zimbabwe (represented by Dr Evelyn Chiyevo Garwe);

(vii) Representative of Central Africa from the Great Lakes Organisation (CEPGL) in Rwanda; and

(viii)Representative of Northern Africa from the Arab Council of Quality Assurance and Accreditation in Jordan (represented by Professor Mohamed Rafat Mahmoud).

(ix) Observers

1. The African Union Commission (AUC);

2. The African Development Bank (AfDB);

3. The United Nations Education and Scientific and Cultural Organization (UNESCO); and

4. The World Bank.

c) The Secretariat, which has the responsibility of undertaking the day-to-day work of the Network (administration, policy, accounting, publications). The Secretariat is currently hosted by the AAU in Accra, Ghana.

AfriQAN contributes to the development and promotion of QA in higher education in the African continent through sharing information, experience, good practice and innovations with members and other stakeholders through platforms such as conferences, workshops, seminars, publications, projects and website. AfriQAN supports members in identifying development partners, experts and collaborators in quality assurance. It also undertakes Peer Reviews of African National QA Agencies on request. In some instances it supports its members financially, for example, in October 2016 AfriQAN assisted the Council on Higher Education (CHE) of Lesotho to identify experts to evaluate the adherence of CHE to its mandate. In addition, AfriQAN provided funding for the experts' airfare. One of the authors of this chapter was among the team of assessors. AfriQAN encourages and supports the establishment of subregional QA networks. To this end it has assisted in the establishment of the Southern African Quality Assurance Network (SAQAN).

\subsubsection{Southern African Quality Assurance Network ( $S A Q A N)$}

In an effort to promote and strengthen QA systems in Southern Africa and in keeping with the encouragement from AfriQAN to establish sub-regional QA networks, ZIMCHE convened the first ever sub-regional (Southern Africa) conference on QA in Higher Education in Victoria Falls, Zimbabwe in July 2014. ZIMCHE took its mandate from the fact that it represents the Southern Africa region in the Executive Board of AfriQAN. Participants were drawn from Southern Africa, AfriQAN and relevant facilitators were invited from international QA organisations. The conference delegates resolved to establish a QA network for Southern Africa which would work in close collaboration with AfriQAN in expediting linkages among members. This would enable sub-regional harmonisation and the enhancement of quality in higher education through the 
sharing and exchange of information on approaches, best practices, relevant experiences and strategies [22]. It was further agreed that annual conferences on QA on higher education will the organised wherein countries would rotate the hosting [22].

A task team led by the Chief Executive Officer of ZIMCHE, was appointed to draft a constitution for the network. The task team which comprised of Heads of national QA agencies from Zimbabwe; Botswana, South Africa, Lesotho and Namibia met in Windhoek, Namibia from 7 to 9 December 2014. The team deliberated on the constitution of the proposed Southern African Quality Assurance Network (SAQAN) which had been drafted by the NCHE of Namibia through assistance from an advocate that they had hired [23]. The constitution of SAQAN was approved and officially launched by the Assistant Minister of Education in Botswana during the $2^{\text {nd }}$ Sub-Regional Conference on QA in Higher Education in Southern Africa that took place in Gaborone, Botswana in October 2015. This conference was jointly organised by the Botswana Qualifications Authority (BQA) and the Human Resource Development Council (HRDC) of Botswana. An Interim Executive Committee with the members listed below was selected to spearhead SAQAN activities pending the election of a substantive Committee:

(i) Prof E. A. Ngara: Zimbabwe Council for Higher Education (Interim President)

(ii) $\mathrm{Mr}$ A. Modungwa: Botswana Qualifications Authority (Interim Vice President)

(iii) Prof N. Baijnath: Council on Higher Education, South Africa (Member)

(iv) $\mathrm{Mr}$ M. Shivute: National Council for Higher Education, Namibia (Member)

(v) Mrs M. T. Motseko: Council on Higher Education, Lesotho (Member)

(vi) $\mathrm{Mr}$ M. Dlamini: National Council for Higher Education, Swaziland (Member)

(vii) Dr E. C Garwe: Zimbabwe Council for Higher Education (Secretary)

The first Annual General Meeting (AGM) of SAQAN was hosted by CHE, South Africa and was held back-to-back with the $3^{\text {rd }}$ conference on Quality Assurance in Higher Education from the $19^{\text {th }}$ to the $21^{\text {st }}$ of October 2016. The AGM adopted BQA's recommendation to host the SAQAN Secretariat in Gaborone and to appoint Dr Phetolo Modiega as the SAQAN Coordinator. Dr Modiega has since been replaced by Dr Violet Nomalanga Essilfie who is the new SAQAN Coordinator with effect from 2017. The rationale was to facilitate regular communication with the Southern African Development Community (SADC) Secretariat which is also housed in Gaborone. SADC is the regional organisation working towards the integration of the region. The interim Committee was confirmed as the SAQAN Executive until the next AGM with the only change being the replacement of the Secretary by a Coordinator.

According to the Constitution of SAQAN, the key functions of the regional network are to: (i) Promote the creation of effective and efficient quality assurance and accreditation mechanisms in higher education within Southern Africa;

(ii) Support the development of quality assurance through capacity building, exchange of staff and internships, seminars, workshops and conferences;

(iii) Disseminate information through newsletters, journals, books and other documents, in print and electronic forms;

(iv) Participate and collaborate in continental and international training and research programmes within Southern Africa;

(v) Mobilise resources to sustain the Network's projects and programmes;

(vi) Develop and maintain a database of quality assurance bodies and experts; and

(vii) Create and maintain a website of the Network.

SAQAN recognises work done in quality assurance by other initiatives in the Southern African Development Community (SADC) sub-region like the Southern African Regional Universities Association (SARUA), the SADC Technical Committee on Certification and Accreditation and the now defunct Higher Education Quality Management Initiative of Southern Africa (HEQMISA). SAQAN's activities are guided by the SADC Protocol on Education as well as the Addis Ababa Convention (revised Arusha). SAQAN has been promised capacity building support in terms of expertise from IUCEA and financial support from development agencies including UNESCO and the German Academic Exchange Service (DAAD). UNESCO contributed to the funding of the $1^{\text {st }}$ and $2^{\text {nd }}$ sub-regional conferences.

\subsubsection{The International Network of Quality Assurance Agencies in Higher Education}

The International Network of Quality Assurance Agencies in Higher Education (INQAAHE) is an international network of QA agencies and providers. It currently has 250 members from all the continents. Full membership is a preserve of National QA agencies who satisfy conditions for joining [24]. INQAAHE's role is to facilitate collaboration, inclusiveness and efficiency among higher education QA agencies. INQAAHE's impact and influence worldwide is well recognised [25]. INQAAHE closely monitors global external QA in order to identify issues and trends and institute appropriate measures and responses. INQAAHE uses Guidelines of Good Practices (GGPs) as a barometer for enhancing QA. These guidelines were recently revised in order to open up opportunities for recognition of QA agencies. INQAAHE also avails access to a database of Experts, Peer Reviewers and Consultants to its members as well as a Query service.

The objectives of INQAAHE are to:

(i) Nurture and support linkages among QA agencies;

(ii) Enhance quality of higher education through advancing QA theory and practice by commission and undertaking relevant QA research;

(iii) Facilitate the sharing of information on QA good 
practices and experiences;

(iv) Proffer advice and provide expertise to members on QA;

(v) Provide support to members to develop and utilise credit accumulation and transfer systems to encourage the mobility of students nationally and internationally;

(vi) Assist members on benchmarking and assessment of foreign qualifications;

(vii) Update members with information regarding corrupt QA practices and institutions;

(viii)Undertake assessments and reviews of the adherence of its members to INQAAHE guidelines of good practice; and

(ix) Represent its members in international platforms on QA issues.

National quality assurance agencies from the following African countries are currently members of INQAAHE: South Africa, Kenya, Lesotho, Ghana, Namibia and Mauritius.

\subsection{Model 2: Cross-Border Quality Assurance and Mutual Recognition of Qualifications}

This model involves national quality assurance agencies in the same regional block having common higher education quality assurance arrangements in order to guarantee comparability of qualifications thus enhancing regional mobility and integration. Examples of regional and international bodies operating using this model are the InterUniversity Council for East Africa (IUCEA) and the Africa and the Conseil Africain et Malgache pour l'Enseignement Superieur (CAMES) (African and Malagasy Council for Higher Education).

\subsubsection{The Inter-University Council for East Africa (IUCEA)}

IUCEA was established by the East African Community (EAC) to assure quality in higher education in order to propel socio-economic development in East Africa. The IUCEA although so named in 1980, was founded in 1970 as an interuniversity committee of the then existing three public universities; Makerere University, University of Nairobi and the University of Dar es Salaam in Uganda, Kenya and Tanzania respectively. These three countries have shared a common higher education area for a long time and have now admitted Burundi and Rwanda into their realm.

The full members of IUCEA comprise of the national QA agencies in East Africa namely: the Commission for University Education in Kenya; the National Commission for Higher Education in Burundi; the National Council for Higher Education in Uganda; the Higher Education Council in Rwanda; the National Council for Technical Education, Tanzania and the Tanzania Commission for Universities. In excess of 90 higher education institutions in East Africa are associate members the majority of whom are private institutions.

The objectives of IUCEA are: (i) facilitating networking amongst members, external agencies and stakeholders;

(ii) providing a platform for exchange of information on issues pertaining to higher education and research;

(iii) working with national QA agencies in the EAC member states;

(iv) improving standards of higher education

(v) establishing harmonization mechanisms to facilitate mobility through mutual recognition of accredited institutions and programmes

(vi) build capacity in QA for Peer Reviewers and staff in QA agencies and HEIs

(vii) development of Programme Benchmarks

Although the national QA agencies of the five member countries of IUCEA are mandated to implement their respective national QA frameworks, these are harmonised in line with the IUCEA guidelines. This includes common quality benchmarks, indicators and outcomes and a harmonised credit accumulation and transfer system which allows for comparability and enables easy mobility of students and staff and strengthens the East Africa higher education area. The common QA system for East African higher education was introduced in 2006 and in 2007 the IUCEA with the support of the German Federal Ministry for Economic Cooperation and Development, DAAD, the University of Oldenburg and the German Rectors' Conference developed a handbook with guidelines on QA featuring four volumes.

The IUCEA is acknowledged by the African Union to be a good model to follow in its pursuit to establish the Pan African Quality Assurance and Accreditation Framework (PAQAF). It has contributed to integration of systems of higher education in East Africa, in a manner akin to the Bologna Process in the European context [26].

\subsubsection{The African and Malagasy Council for Higher Education (CAMES)}

CAMES was established to address issues of QA in higher education in the French- speaking nations in Africa and Malagasy in 1968. It is a network of 19 countries namely: Burkina Faso, Benin, Burundi, Cameroon, Central African Republic, Congo, Democratic Republic of Congo, Equatorial Guinea, Ivory Coast, Gabon, Guinea, Guinea Bissau, Madagascar, Mali, Niger, Rwanda, Chad, Senegal, and Togo.

The aim of establishing CAMES was to harmonise and coordinate higher education policies and programmes in the member countries in order to enhance quality as well as to create a common higher education space. CAMES achieved this objectives through the use of minimum agreed standards for quality. These were developed through a process involving three stages. The initial stage involved a baseline survey on the areas requiring standards. They then identified experts to come up with draft standards. These experts included discipline-specific specialists from higher education institutions, professionals and students (current and alumni). The final stage included validation, editing and approval of the minimum benchmarks, standards or guidelines for 
improving the higher education delivery system. To date CAMES has implemented the following QA initiatives:

(i) Licence-Master-Doctorate (LMD) reform;

(ii) Mutual recognition of qualifications; and the

(iii) Capacity-building programme in QA.

The initiatives of CAMES and the achievements thereof are aptly described by [22].

\subsection{Model 3: Central Accreditation}

The third model involves a conceptual framework of the meta-accreditation of QA systems and bodies culminating in accreditation and international recognition of QA bodies. An example include the proposed Continental Quality Assurance and Accreditation Agency for Africa.

The establishment of the Pan African Quality Assurance and Accreditation Agency for Africa is a grant plan by the AUC aimed at creating a competitive African higher education space. The proposed agency is aimed at assessing, comparing and harmonising standards of higher education in order to enable mobility of students, staff and labour in Africa. The agency will be responsible for administering the Pan African Quality Assurance Framework (PAQAF) that will be used for quality assurance and accreditation purposes in order to ensure adherence to common set standards. The continental accreditation agency will be mandated to accredit national and other quality assurance agencies as well as assisting countries to establish quality assurance bodies in countries where they have not yet been established. The proposed accreditation agency will have partnerships with other regional and international QA agencies and initiatives. The continental agency is also intended to accredit the Pan-African Universities. Pan-Africa Universities are regional universities that are being established across Africa to address identified areas of manpower shortage.

Although this model is desirable, its success is likely to be hampered by vested national and regional interests arising from the fact that as a continent, Africa has many disparate education systems featuring varied languages of instruction, credit systems, university entry requirements and leadership capabilities. Adequate funding and legal issues are also potential challenges.

\subsection{Model 4: Cross-Border Quality Assurance and Accreditation Arrangements}

This model focuses on quality assurance arrangements on the international level and is totally different from the first three whose primary focus is on strengthening the national quality assurance bodies. Examples are the Regional Universities Forum for capacity building (RUFORUM) and the European Consortium of Innovative Universities (ECIU).

\subsubsection{The Regional Universities Forum for Capacity Building (RUFORUM)}

The University of Makerere in Uganda is where the offices of the Regional Universities Forum for Capacity Building in Agriculture (RUFORUM) are located. RUFORUM, which started as a programme of the Rockfeller Foundation, is a consortium of 32 universities in Eastern, Central and Southern Africa and was established in 2004. The forum oversees graduate training and networks of specialization in the Common Market for Eastern and Southern Africa (COMESA) countries. This comes about because of its recognition of the important and largely unfulfilled role that universities play in contributing to the well-being of smallscale farmers and economic development throughout subSaharan Africa. Its hallmark is fostering innovative and responsive research; high performing and proactive graduates; a dynamic platform for university networking; advocacy for agricultural higher education; and university transformation for relevance.

According to the RUFORUM 2011-2016 Business Plan the Strategic Goals of RUFORUM are to:

(i) Train a critical mass of $\mathrm{MSc}$ and $\mathrm{PhD}$ graduates who are responsive to stakeholder needs and development goals;

(ii) Develop collaborative research and training facilities that achieve economies of scope and scale;

(iii) Increase the participation and voice of women in research, production and marketing;

(iv) Improve adaptive capacities of universities to produce high quality and innovative training, research, and producing high quality outreach services;

(v) Increase the use of technology to support effective, decentralised learning and sharing of knowledge;

(vi) Mainstream new approaches within university teaching/research that have impact across the agricultural sector's full value chain; and

(vii) Create a dynamic regional platform for policy advocacy, coordination, and resource mobilisation for advanced learning/doing.

\subsubsection{European Consortium of Innovative Universities (ECIU)}

The ECIU was founded in 1996, as an international association of research intensive higher education institutions that aim towards socio-economic development through emphasising creativity, innovation and technology [28]. At its genesis the EECIU member institutions were from regions that had suffered industrial decline and needed to resuscitate industrialisation. This consortium has made great strides in teaching and learning innovations, internationalising its staff and students, encouraging interaction between universities and society research and entrepreneurship as well as in participating in development of policies. ECIU currently has 12 European full members and three associate members from Australia, Mexico and Russia.

The objectives of ECIU are to:

(i) Foster collaboration in the development of appropriate programmes that address the needs of member countries, by building on research and teaching strengths within individual ECIU member institutions;

(ii) Research on innovative ways of enhancing quality of the teaching and learning experience; 
(iii) Leading by example in spreading best practices, stimulating dialogue and contributing to policy on higher education in a dynamic global environment;

(iv) In the member institutions, in the areas of: international collaboration; regional development; technology transfer; and staff and student development; and

(v) Foster economic growth through research and collaboration with of ECIU associate members.

\section{Discussion}

These different models discussed show the possibility of countries in different regions and in the world to harmonise their higher education through the use of minimum quality standards. The process of doing so includes consultations and consensus building by higher education stakeholders from all the countries represented. This will ensure that the diversities and uniqueness of the different national and regional contexts are embraced and that the resultant standards are implementable. Political will is critical in setting up the requisite implementing structures at national, regional and international level and in providing the necessary resources and funding. Thus it can be summed up that the success of regional and international quality assurance and accreditation arrangements hinge on developing and implementing common standards, policies, tools and instruments thorough stakeholder involvement, political support and commitment. This will create fertile ground for fostering harmonisation and comparability of higher education systems and qualifications. The ensuing confidence and trust creates quality regional and international higher education spaces.

\section{Conclusion}

Because each of the four models discussed has its strengths and weaknesses, no particular model is recommended. However, by adopting good practices from the four models, it is possible to foster greater regional and international cooperation as a way of responding to the regulatory demands of globalisation and enhancing quality.

\section{References}

[1] Brennan, J. and Shah, T. (2000) Managing quality in higher education: An international perspective on institutional assessment and change. Buckingham, UK: OECD, SRHE \& Open University Press.

[2] Lee, M., and Healy, S. (2006). Higher Education in Southeast Asia: An Overview. In Higher Education in Southeast Asia. UNESCO Asia and Pacific Regional Bureau for Education.

[3] Oyebade, S. A., Oladipo, S. A., and Adetoro, J. A. (2012). Determinants and strategies for quality assurance in Nigeria University education.

[4] Pillay, P. (2011). Higher Education and Economic
Development. Centre for Higher Education Transformation (CHET), pp. 43-44.

[5] Schendel, R., McCowan, T. y Oketch, M. (2014). The economic and noneconomic benefits of tertiary education in low-income contexts. International Higher Education. 77: 6-8.

[6] Yang, J., Schneller, C., \& Roche, S. (Hrsg.). (2015). The role of higher education in promoting lifelong learning (S. 17-39). Hamburg: UNESCO Institute for Lifelong Learning.

[7] Holm-Nielsen, L., Thorn, K., Brunner, J. J., and Balán, J. (2005). Regional and international challenge to higher education in Latin America. In: De Wit, H., Jaramillo, I., Gacel-Ávila, J. and Knight J. (Eds.), Higher education in Latin America. The international dimension (pp. 39-69). Washington, DC: World Bank.

[8] Hahn, K., Teferra, D. (2013). Tuning as instrument of systematic higher education reform and quality enhancement: the African experience. Tuning Journal for Higher Education. 1:127-163.

[9] Reichert, S. (2010). The intended and unintended effects of the Bologna reforms. Higher Education Management and Policy 22, no. 3: 59-78.

[10] Salter, B., and Tapper, T. (2000). The politics of governance in higher education: The case of quality assurance. Political Studies. 48:66-87. Doi:10.1111/1467-9248.00251.

[11] Wells, P. J. (2014). The DNA of a Converging Diversity: Regional Approaches to Quality Assurance in Higher Education Higher Education. Washington D. C.: Council for Higher Education Accreditation. UNDP (2012), World Population Prospects: The 2010 Revision.

[12] Westerheijden, D. F., Stensaker, B., and Rosa, M. J. (Eds.). (2007). Quality assurance in higher education. Dordrecht: Springer.

[13] Coleman, D. (2003). Quality assurance in transnational education. Journal of Studies in International Education. 7:354-378. Doi: 10.1177/1028315303255597.

[14] Kehm, B. (2003). Internationalisation of higher education: From regional to global. In: Begg, R. (Ed.). The dialogue between higher education research and practice (pp. 109-119). Dordrecht: Kluwer.

[15] Verger, A. (2010). WTO/GATS and the global politics of higher education. New York, NY: Routledge.

[16] Stensaker, B. (2013). Ensuring quality in quality assurance. In: Transparency International (Ed.), The global corruption report: Education pp. 124-132. New York, NY: Routledge.

[17] Stella, A. (2006). Quality Assurance of Cross-border Higher Education. Quality in Higher Education, 12 (3), New York, NY: Routledge pp. 257-76.

[18] Wells, P. J. (2014). The DNA of a converging diversity: Regional approaches to quality assurance in higher education. Retrieved from the Council for Higher Education Accreditation (CHEA).

[19] Youssef, L. (2014). Globalisation and higher education: from within-border to cross-border. Open Learning: The Journal of Open, Distance and e-Learning, 29 (2), pp. 100-115.

[20] Shin, J. C., Postiglione, G. A. and Huang, F. (2015). Mass higher education development in East Asia: Strategy, quality, and challenges. Available online at: http://www.springer.com/us/book/ 9783319126722. 
[21] Van Damme, D., (2002). Trends and Models in International Quality Assurance and Accreditation in Higher Education in Relation to Trade in Education Services. OECD/US Forum on Trade in Educational Services, 23-24 May, Washington, DC.

[22] Shabani, J., Okebukola, P., and Oyewole, O. (2014). Quality assurance in Africa: Towards a continental higher education and research space. International Journal of African Higher Education 1 (1).

[23] National Council for Higher Education (NCHE) (2014a). Conference statement on the First Southern Africa SubRegional Conference on Quality Assurance in Higher Education: 3-4 July 2014, Victoria Falls, Zimbabwe. Retrieved from http://www.nche.org.na/medstat3.php.

[24] National Council for Higher Education (NCHE) (2014b). Report on the First Task Team Meeting of the Southern Africa Sub-Regional Network on Quality Assurance in Higher Education. Windhoek, Namibia.
[25] Woodhouse, D. (2001). Australian Universities Quality Agency: Audit Manual ( version 0 ed.). Canberra: DEST.

[26] Lemaitre, M. J. (2014). Quality assurance in Latin America. In: Rosa, M. J. and Amaral, A. (Eds.), Quality assurance in higher education. Contemporary debates (pp. 160-177). New York, NY: Palgrave Macmillan.

[27] Nkunya, M. H. H., Bienefeld, S and Hansert, C. (2014). Developing internal QA mechanisms - Towards an East African Quality Assurance framework. Available online at: https://www.eurashe.eu/library/quality-he/Ia.8\%20\%20Bienefeld_Nkunya_Hansert.pdf.

[28] Hansen, S. L., Kokkeler, B., and van der Sijde, P. C. (2002). Regional Development and the European Consortium of Innovative Universities. Industry and Higher Education. 16, (2):77-81. 